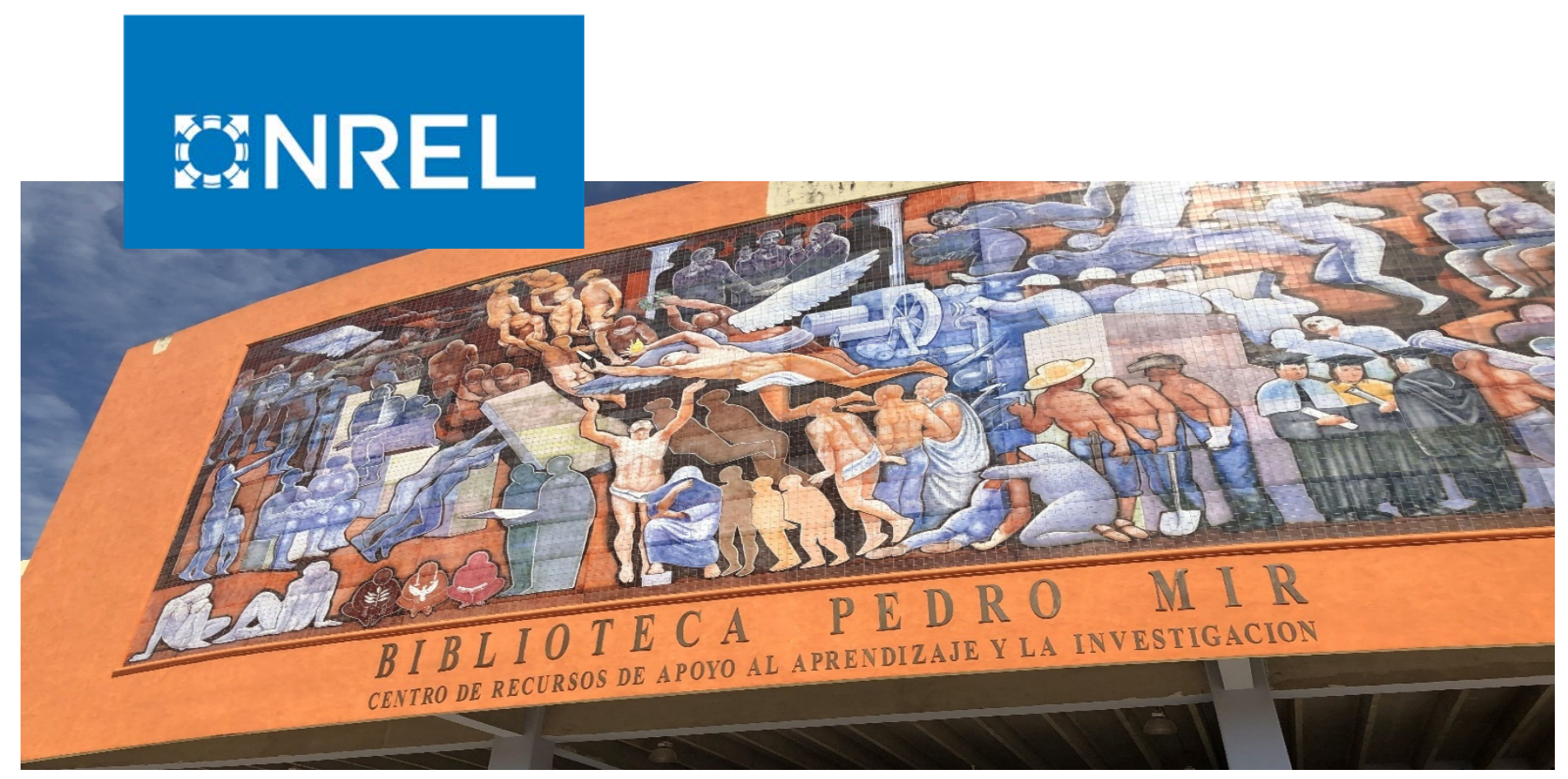

\title{
Assessment of the Dominican Republic's Commercial and Industrial Energy Efficiency Sector
}

Jonathan Morgenstein, Bethany Speer, and Ricardo Castillo

National Renewable Energy Laboratory

Supported by:

䎆 | Federal Ministry

for the Environment, Nature Conservation

and Nuclear Safety

based on a decision of the German Bundestag

NREL is a national laboratory of the U.S. Department of Energy

Office of Energy Efficiency \& Renewable Energy

Operated by the Alliance for Sustainable Energy, LLC

This report is available at no cost from the National Renewable Energy Laboratory (NREL) at www.nrel.gov/publications.
Technical Report

NREL/TP-7A40-77611

September 2020 


\section{BNREL}

\section{Assessment of the Dominican Republic's Commercial and Industrial Energy Efficiency Sector}

Jonathan Morgenstein, Bethany Speer, and Ricardo Castillo

National Renewable Energy Laboratory

\section{Suggested Citation}

Morgenstein, Jonathan, Bethany Speer, and Ricardo Castillo. 2020. Assessment of the Dominican Republic's Commercial and Industrial Energy Efficiency Sector. Golden, CO: National Renewable Energy Laboratory. NREL/TP-7A40-77611.

https://www.nrel.gov/docs/fy20osti/77611.pdf.

Supported by:

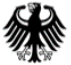

Federal Ministry

for the Environment, Nature Conservation

and Nuclear Safety

based on a decision of the German Bundestag

NREL is a national laboratory of the U.S. Department of Energy Office of Energy Efficiency \& Renewable Energy Operated by the Alliance for Sustainable Energy, LLC

This report is available at no cost from the National Renewable Energy Laboratory (NREL) at www.nrel.gov/publications.

Contract No. DE-AC36-08GO28308
Technical Report

NREL/TP-7A40-77611

September 2020

National Renewable Energy Laboratory 15013 Denver West Parkway Golden, CO 80401

303-275-3000 • www.nrel.gov 


\section{NOTICE}

This work was authored by the National Renewable Energy Laboratory, operated by Alliance for Sustainable Energy, LLC, for the U.S. Department of Energy (DOE) under Contract No. DE-AC36-08GO28308. Funding provided by SouthSouthNorth through the German International Climate Initiative. The views expressed herein do not necessarily represent the views of the DOE or the U.S. Government.

This report is available at no cost from the National Renewable Energy Laboratory (NREL) at www.nrel.gov/publications.

U.S. Department of Energy (DOE) reports produced after 1991 and a growing number of pre-1991 documents are available free via www.OSTI.gov.

Cover Photo by Richard Castillo, report co-author.

NREL prints on paper that contains recycled content. 


\section{Acknowledgments}

Since 2017, the National Renewable Energy Laboratory (NREL) has been active in providing a series of technical assistance and capacity building efforts in the Dominican Republic, centered on mobilizing investment in the Dominican Republic's Nationally Determined Contributions (NDC) priority areas. As part of this effort, NREL led the establishment of, and has worked closely with, a task force of diverse stakeholders. The task force's members include the World Bank, Inter-American Development Bank (IADB), and Germany’s Gesellschaft für Internationale Zusammenarbeit (GIZ) the Dominican Ministry of Energy and Mines (MEM), the Dominican stock exchange, the exchange's government regulatory agency, as well as the industry associations of the Dominican Republic's commercial banks and charitable investment foundations. ${ }^{\mathrm{i}}$

Through these efforts, together with its work alongside La Asociación de Industrias de la República Dominicana, NREL has deepened its understanding of the Dominican Republic clean energy market, especially in regards to energy efficiency opportunities.

This report has been written as part of a grant agreement with SouthSouthNorth, funded by the German International Climate Initiative-Internationale Klimaschutzinitiative. Its authorship was not requested by the Dominican Republic government but is intended to respond to interest expressed by public and private sector stakeholders in the country to understand how to further promote clean energy investments.

The authors also wish to thank and acknowledge: NREL's Riccardo Bracho, Karlynn Cory, Jeffrey Logan, Isabel McCan, Liz Breazeale, and Camille White; Charles De La Rosa of GIZ; as well as Eduardo Sierra Gonzalez, Luis Rodrigo Chaparro Montana, and Omar Villacorta Alvarez of the IADB, for their assistance at various junctures, to ensure this report could find its way to completion.

\footnotetext{
i The complete list of initial task force participants beyond NREL includes international organizations (InterAmerican Development Bank, International Finance Corporation/World Bank Group, Deutsche Gesellschaft für Internationale Zusammenarbeit, GmbH, European Investment Bank, Frankfurt School of Finance and Management, and HPL LLC Sustainable Finance Advisory), Dominican government agencies (Ministerio de Energía y Minas, Superintendencia del Mercado de Valores, and Bolsa y Mercados de Valores de la Republica Dominicana), as well as Dominican industry associations and private foundations (Fundación Reservas del País, Asociación de Bancos Comerciales de la República Dominicana, Asociación Dominicana de Sociedades Administradoras de Fondos de Inversión).
} 


\section{List of Acronyms}

$\begin{array}{ll}\text { C\&I } & \begin{array}{l}\text { commercial and industrial } \\ \text { CCHP }\end{array} \\ \text { CFL } & \text { compined cooling heating and power } \\ \text { CHENACT } & \text { Caribbean Hotel Energht Efficiency and Renewable Energy Programme } \\ \text { CNE } & \text { Comisión Nacional de la Energía } \\ \text { CODIA } & \text { Colegio Dominicano de Ingenieros, Arquitectos y Agrimensores } \\ \text { ECM } & \text { energy conservation measure } \\ \text { ESCO } & \text { energy service company } \\ \text { ESPC } & \text { energy savings performance contract } \\ \text { GDP } & \text { gross domestic product } \\ \text { HVAC } & \text { heating, ventilation, and air conditioning } \\ \text { IDB } & \text { Inter-American Development Bank } \\ \text { LCOE } & \text { levelized cost of electricity } \\ \text { LED } & \text { light emitting diode } \\ \text { MEM } & \text { Ministry of Energy and Mines } \\ \text { NDC } & \text { Nationally Determined Contribution } \\ \text { NREL } & \text { National Renewable Energy Laboratory } \\ \text { POA } & \text { plan of action } \\ \text { PV } & \text { photovoltaic } \\ \text { RISE } & \text { Regulatory Indicators for Sustainable Energy }\end{array}$




\section{Executive Summary}

In this report, the National Renewable Energy Laboratory (NREL) explores the commercial and industrial (C\&I) energy efficiency market in the Dominican Republic, including the market's current status. During NREL's engagement with its Dominican counterparts, NREL noted market gaps that were identified by both public and private sector market actors. The intent of this paper is twofold. First, to help potential customers, project financing institutions, and various government agencies understand where the energy efficiency sector stands in 2020. Second, to help stakeholders recognize the scope, scale, and opportunity for cost-effective energy savings. This research identified how these potential energy efficiency savings could be realized through improvements to the enabling environment, technical capacity, and level of activity in the sector. Moreover, it determined that through taking action to catalyze energy efficiency investments, the government could make significant progress towards its self-declared Nationally Determined Contribution (NDC) goals, and result in significant savings across the Dominican economy for both the private and public sectors.

Throughout the research for this report, NREL used publicly available data provided by the Dominican government, as well as information shared by private Dominican companies. Using international standard calculation methodologies, NREL demonstrated that increased investment in energy efficiency could significantly reduce both private and public annual operating expenses.

In 2016 the World Bank asked Dominican companies to name the "biggest obstacle" to their businesses. Electricity was the second most commonly-cited challenge. Among small businesses, electricity was the most cited obstacle (The World Bank 2016a). In 2018, electricity constituted over $80 \%$ of total energy consumption by the Dominican commercial sector (CNE 2020a), and a regional study indicated that energy efficiency investments could save hotels as much as $13 \%$ off the hotels' total operating costs, not just off their energy costs (Konold, Lucky et al. 2015).

Energy efficiency can benefit the public sector as well, saving the Dominican government money through energy investments in two ways. First, the government can save on lower public sector energy bills due to widespread energy efficiency upgrades. Second, the government could realize significant savings by lowering payouts in electricity (both retail, and upstream) subsidies to all customers. In fact, direct retail electricity subsidies alone consumed over $2.5 \%$ of the federal government's budget in both 2018 and 2019 (Dirección de Regulación 2020; Banco Central 2020).

The Dominican government, therefore, has begun cultivating a stronger energy efficiency market to reduce both public and private budget outlays on energy expenditures. The outgoing administration set in motion multiple initiatives to support energy efficiency. Such efforts have included initiating the development of a comprehensive climate action plan - with a conditional 2030 emissions reduction target of $25 \%$ off base-year emissions - to actualize the pledges of its 2015 published NDCs.

Additionally, there are some indications the new Dominican administration will continue and build upon these initiatives as the incoming President and his new Minister of Energy have spoken about the need to "expand the use of renewable energy to reduce the carbon footprint" 
(Guzmán Then 2019). They have also emphasized that "sustainability and efficiency are decisive to achieving the productive and competitive potential of an economy" (N Digital 2020a), and that their administration "will be the government of clean and sustainable practices" (N Digital 2020b).

As of August 2020, energy efficiency still retains significant space to grow across the Dominican economy. Some potential reasons that energy efficiency has yet to reach its potential are: (1) lack of market education among multiple stakeholders including potential customers, financing institutions, and project implementors; (2) lack of available, affordable project financing; and (3) shortage of energy efficiency implementation expertise. 


\section{Table of Contents}

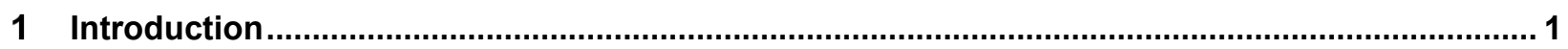

2 Energy Sector Overview: Potential Benefits of Energy Efficiency............................................ 2

3 Dominican Government Energy Efficiency Policy ..................................................................... 5

3.1 Room for Improvement in Government Energy Efficiency Policy........................................... 5

3.2 Government's Growing Energy Policy Attention .................................................................. 7

3.2.1 La Comisión Nacional de la Energía’s Energy Audits and Labelling .............................. 7

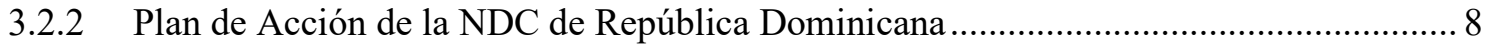

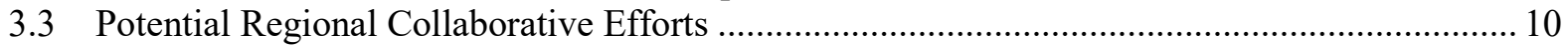

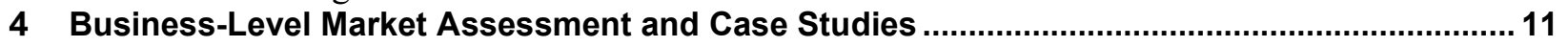

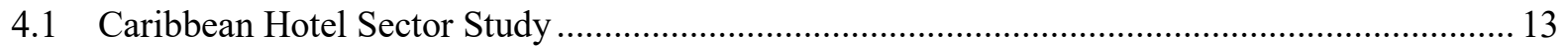

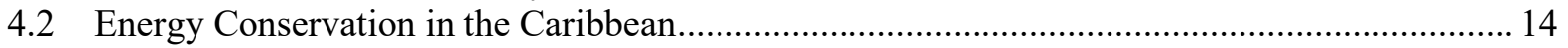

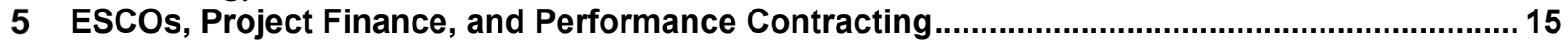

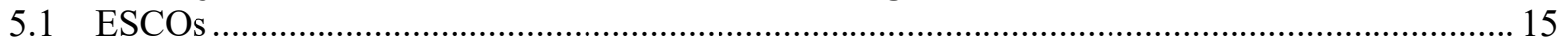

5.2 Project Financing Challenges and Low-Information Actors................................................. 15

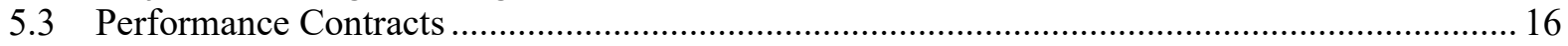

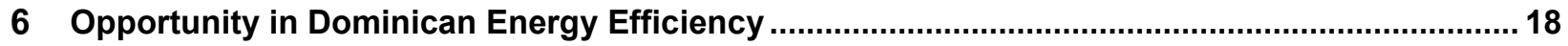

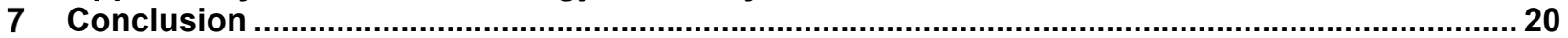

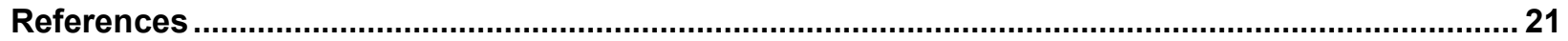




\section{List of Figures}

Figure 1. 2000-2019 Dominican Republic direct retail electricity subsidies .......................................... 2

Figure 2. 2018 Dominican Republic comparative levelized cost of electricity (LCOE) ............................ 4

Figure 3. Energy efficiency scores for Latin America and the Caribbean ................................................5

Figure 4. Dominican Republic 2017 World Bank RISE scores............................................................ 6

Figure 5. Top three Dominican Republic business environment constraints........................................... 11

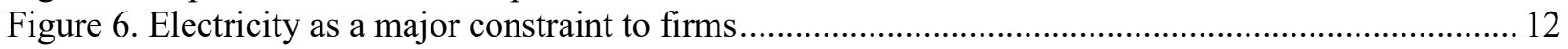

Figure 7. Energy consumption in Dominican hotels by fuel source ...................................................... 13

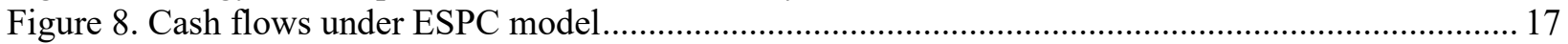

\section{List of Tables}

Table 1. Energy efficiency technologies that may be cost-effective in the Caribbean ............................. 14

Table 2. Savings from Energy Efficiency Measures in Hotels in the Caribbean ...................................... 16

Table 3. SWOT Analysis for Potential Dominican Republic C\&I Customers ......................................... 18 


\section{Introduction}

The National Renewable Energy Laboratory (NREL) has partnered for the last two years with Dominican Republic government agencies, nonprofits, multilateral agencies, financing institutions, and private sector firms. These collaborations have sought to evaluate and potentially develop financing mechanisms to expedite growth of the country's renewable energy and energy efficiency markets towards the benchmarks of the government's stated Nationally Determined Contribution (NDC) goals. Along these lines, in 2019-20, NREL helped lead the establishment of a joint task force (comprising both international and Dominican stakeholders from public, private, and nonprofit sectors) dedicated to improving access to finance for clean energy and energy efficiency investments, such as green bonds.

Additionally, in partnering with the Dominican private sector, NREL has helped to cultivate local technical capacity in areas of solar photovoltaic (PV) deployment and building energy retrofits. Along these lines, NREL has worked with La Asociación de Industrias de la República Dominicana, and its member companies to raise awareness of the utility and cost effectiveness of investment in energy conservation measures (ECMs) and other efficiency investments, including executing pilot energy audits for key Dominican corporations.

Lastly, working with the Dominican Republic's government, NREL has provided technical assistance on policy design to enable accelerated adoption of distributed PV deployment, and the scaling up of all facets of the energy efficiency sector.

Through these efforts, NREL has developed a rich understanding of the diverse aspects of the Dominican energy efficiency market, including ways in which it has improved, and aspects where gaps still exist.

This report is a higher-level assessment of energy efficiency in the Dominican Republic, rather than a detailed, comprehensive survey of the sector. It is intended to be used to assist the private and public sectors alike to understand in general terms where the market stands, and opportunities to catalyze the market's growth. 


\section{Energy Sector Overview: Potential Benefits of Energy Efficiency}

The Dominican Republic every year must import fossil fuels to satisfy $90 \%$ of its energy consumption (Gielen et al. 2016). Similar to most developing island nations, such dependency creates challenges to its energy security, energy reliability, and economic growth. The result is very high energy costs that negatively impact the Dominican Republic's economy and standard of living. Sometimes this burden is born directly by end users, but, other times, by the government.

Between 2015 and 2018, commercial retail electricity prices fell 18.6\% from $\$ 217.00$ per MWh to $\$ 176.60 / \mathrm{MWh}$ (BNEF 2020a). During the same three years, industrial retail prices fell $30.8 \%$ from $\$ 210.69 / \mathrm{MWh}$ in 2015 to $\$ 145.80 / \mathrm{MWh}$ (BNEF 2020a). However, during the same period wholesale electricity prices rose $46 \%$ (BNEF 2020a).

This paradox is only possible because government subsidies have, to a significant degree, untethered retail prices from the true cost of fossil fuel generation. Instead, the Dominican government spends hundreds of millions of dollars in power subsidies annually to keep electricity tariffs artificially low (Gielen et al. 2016). As Figure 1 shows - except in 2015-16 when global oil prices fell by over 55\%, resulting even in a temporary accounting surplus (BP 2020) - direct retail electricity subsidies alone impose a high toll on the Dominican government, consuming over $2.5 \%$ of the federal government's budget in both 2018 and 2019 (Dirección de Regulación 2020; Banco Central 2020). When other energy subsidies impacting electricity are factored in, the burden is even greater. In 2013, all electricity subsidies combined cost the government over $\$ 1$ billion, equal to $2 \%$ of the entire 2013 Dominican gross domestic product (GDP) and over $11 \%$ of the Dominican central government's total expenditure (OECD, IADB 2017). Increasing energy efficiency and renewable energy will reduce the amount each year the government pays-out in subsidies overall.

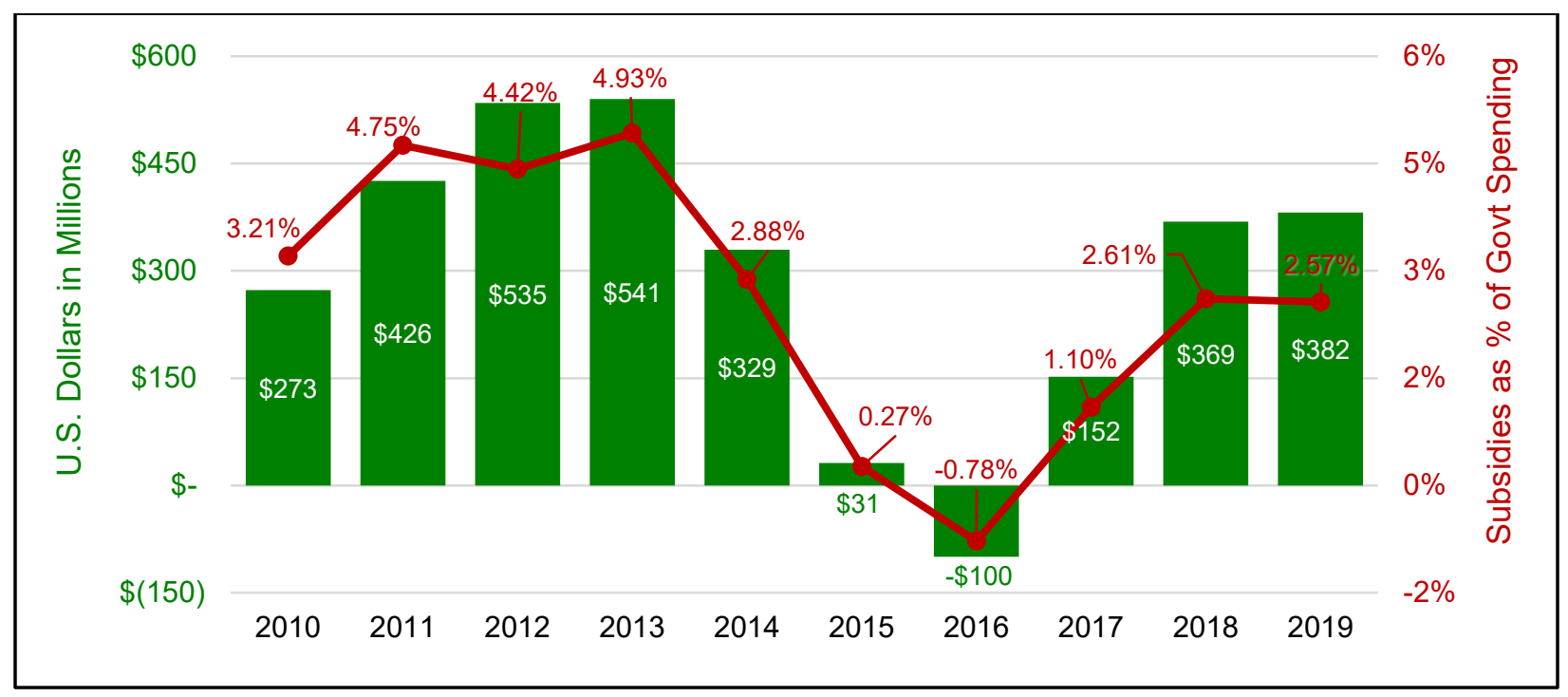

Figure 1. 2000-2019 Dominican Republic direct retail electricity subsidies

Source: (Dirección de Regulación 2020); (Banco Central 2020) 
If there is an upside to these high electricity costs, it is the incentive for both the private and public sectors to invest in energy efficiency and renewable electricity, which can help reduce energy expenditures through both lower use and lower per-unit costs for each $\mathrm{kWh}$ consumed. Additionally, energy efficiency and renewable electricity investment can provide disproportionally large returns because electricity has comprised such a large proportion of overall energy consumption in key Dominican commercial and industrial (C\&I) sectors.

In 2018 , electricity constituted over $80 \%$ of total energy consumption by the Dominican commercial sector (CNE 2020a) (including government and public service buildings), most of which was consumed powering lighting, air conditioning, and appliances (Konold, Lucky et al. 2015). In the restaurant sector, electricity accounted for $57.6 \%$ of energy consumption (CNE 2020a). Of this, the top energy consumers were likely refrigeration, heating, ventilation, and air conditioning (HVAC), and water heating (Konold, Lucky et al. 2015).

As a result, every increase in either energy efficiency or renewable generation, lowers reliance on the volatile price, and accessibility, of imported fossil fuels, thus strengthening Dominican energy security. Moreover, by decreasing both peak demand for electricity and total energy consumption, energy efficiency would likely both lower overall energy costs to the consumer and diminish the rate of cost increases nationally.

By simultaneously investing in renewable generation and ECMs, a customer's renewable energy can offset a larger proportion of the customer's total energy consumption. Moreover, combining the two investments can improve the overall attractiveness of renewable energy procurement, as ECM investments often have shorter payback periods.

Also, with the high cost of Dominican grid electricity, procuring renewable energy likely can save C\&I customers significantly on their operational expenses. Figure 2 (BNEF 2020b; Lazard 2018) shows the 2018 average per-kWh retail tariff for electricity for C\&I customers in the Dominican Republic. These prices are compared to the unsubsidized Dominican, off-site, utilityscale solar energy LCOE, ${ }^{\text {ii }}$ as well as the global average LCOE for on-site C\&I solar and off-site wind. Thus, it is reasonable to posit that procuring on-site solar systems, off-site solar, and offsite wind systems all would cost Dominican C\&I consumers significantly less than buying grid electricity.

Although procuring renewables will likely decrease a company's energy bills, their costs still will be proportionate to the amount of energy they consume. Thus, energy efficiency upgrades in advance of, or combined with, renewables procurement can create synergies of even lower energy costs than investing only renewables or efficiencies by themselves.

\footnotetext{
${ }^{\text {ii }}$ LCOE is "a measure of the overall competitiveness of energy technologies, [that] can be used to assess the economic viability of [an] investment. In particular, the LCOE method consists of comparing the cost to install and operate an energy system and its expected life-time energy output. The calculation is done using the net present value method." (Kost et al. 2013)
} 


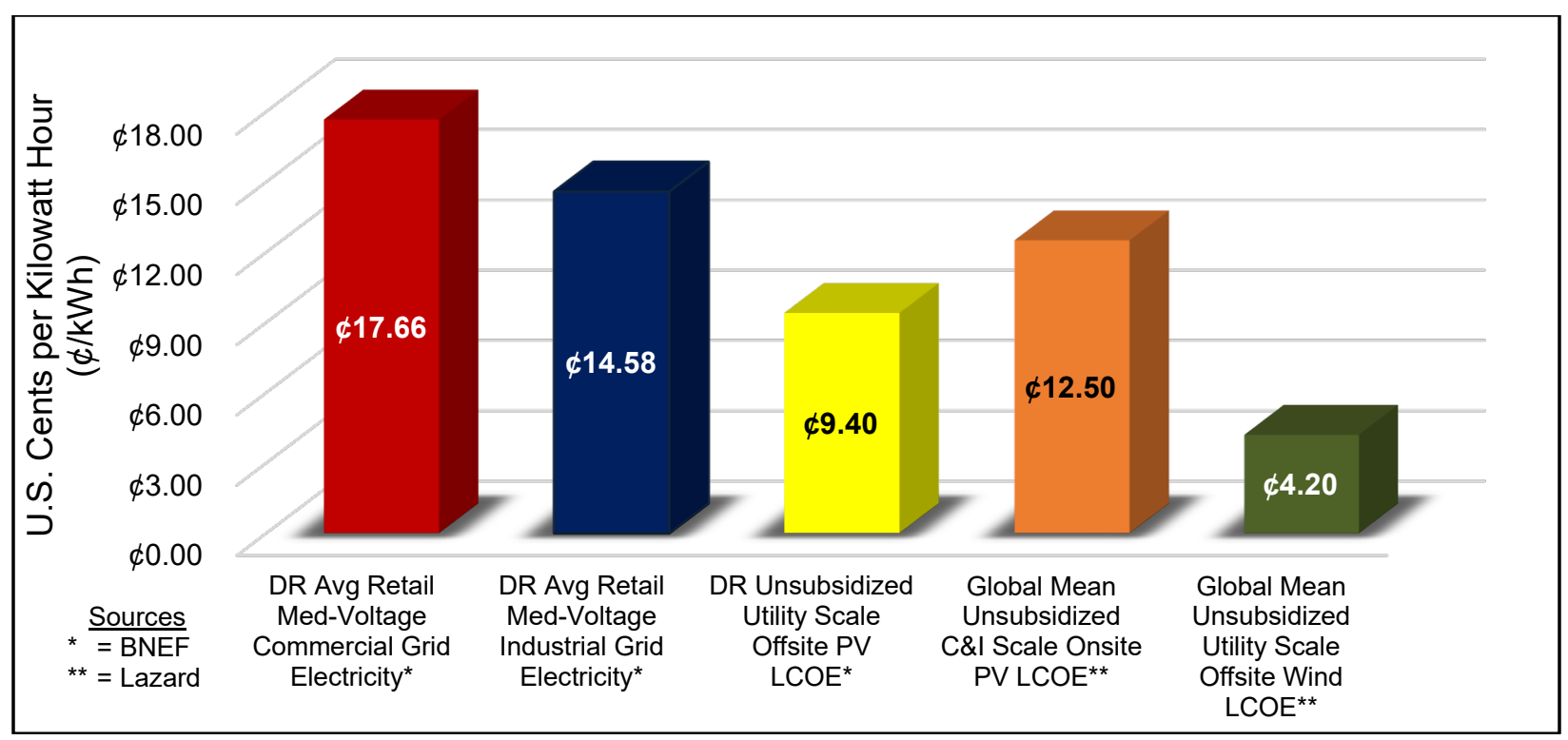

Figure 2. 2018 Dominican Republic comparative levelized cost of electricity (LCOE)

Sources: (BNEF 2020b); (Lazard 2018)

Additionally, energy efficiency investments can provide significant employment benefits as the country begins its recovery from COVID-19's economic impacts. Even before COVID-induced challenges, in a 2019 poll, "lack of job opportunities" was the Dominican Republic's second most-commonly cited problem at 34.7\% (E1 Dia 2019). Energy efficiency upgrades are heavily labor-intensive in higher skilled, better-paid blue-collar jobs. So, such investments can disproportionately expand well-paid employment compared to spending in many other sectors. However, appropriate training and capacity building will likely be required to strengthen the requisite skill sets of the Dominican labor force.

Despite these opportunities to harness multiple significant benefits, energy efficiency investment in the Dominican Republic has remained low. The reasons for this are varied and are described in the following section. 


\section{Dominican Government Energy Efficiency Policy}

Some of the causes of the limited scale of investments appear related to a shortage of regulatory structures supportive of energy efficiency investment in general, and, in particular, of financing mechanisms. Some assessments of the energy efficiency investment environment in the Dominican Republic indicate there is significant opportunity for further developing the enabling environment. This is especially true when government policies that would incentivize such investment, or even simply help provide awareness and credibility to the sector's development, have been rare. The Dominican government has undertaken significant efforts to launch new policies and programs over the past few years; however, many such planned initiatives have yet to be fully launched or scaled.

\subsection{Room for Improvement in Government Energy Efficiency Policy}

In 2017, the World Bank assessed over 130 countries based on their Regulatory Indicators for Sustainable Energy (RISE) (RISE 2017a). The Dominican Republic earned a raw average score of 26 out of $100(0=$ lowest, $100=$ highest $)$ for its energy efficiency enabling environment (RISE 2017b). This ranks it at $92^{\text {nd }}$ out of 136 countries across the globe, and as can be seen in Figure 3, tied for $14^{\text {th }}$ out of 19 Latin America and the Caribbean (RISE 2017a) countries.

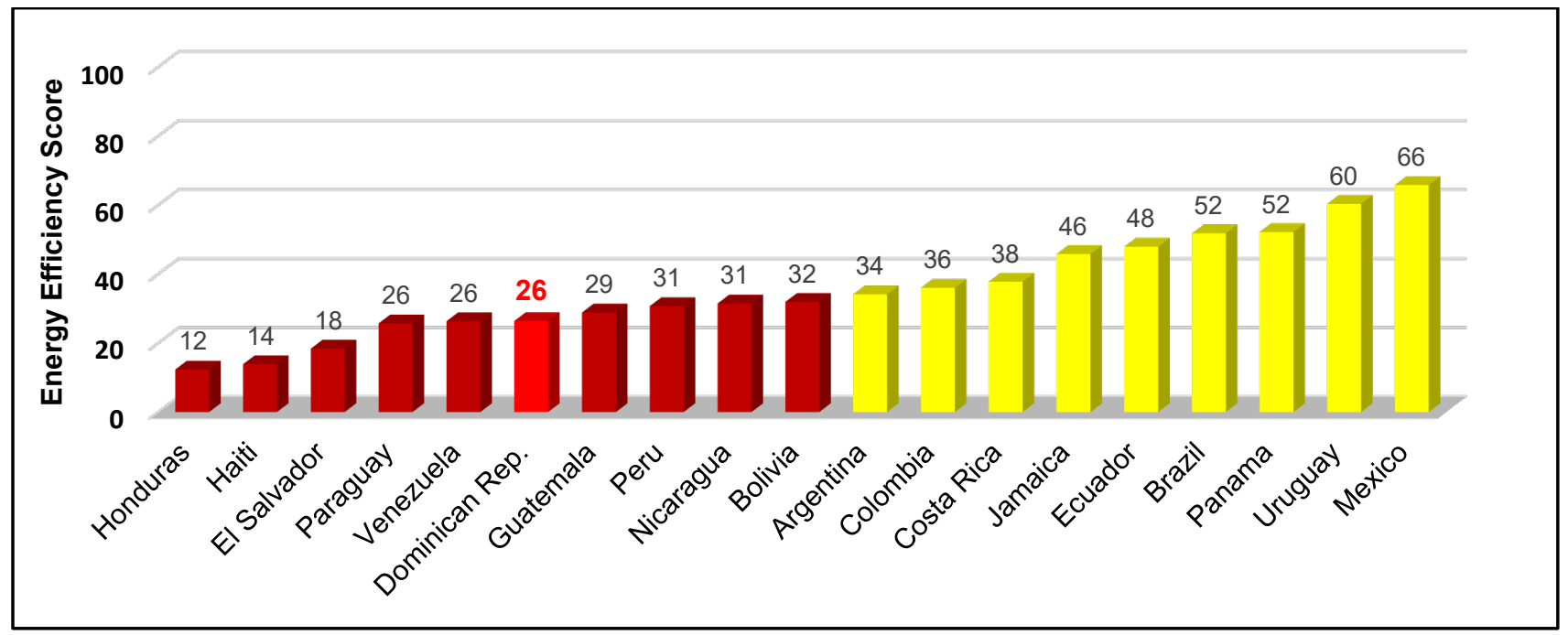

Figure 3. Energy efficiency scores for Latin America and the Caribbean

Source: RISE 2017a

As shown in Figure 4 (RISE 2017b), RISE derived the Dominican Republic's low cumulative score, primarily from the country's: 
- Lack of energy efficiency planning ${ }^{\text {iii }}$

- Low level of compliance enforcement by energy efficiency "entities" iv

- Limited energy efficiency incentives or mandates for C\&I end users, public sector, or utilities

- Lack of minimum energy performance standards

- Absence of building energy codes

- Deficiencies in drivers of energy efficient transport

- Nonexistent carbon pricing and monitoring (RISE 2017b).

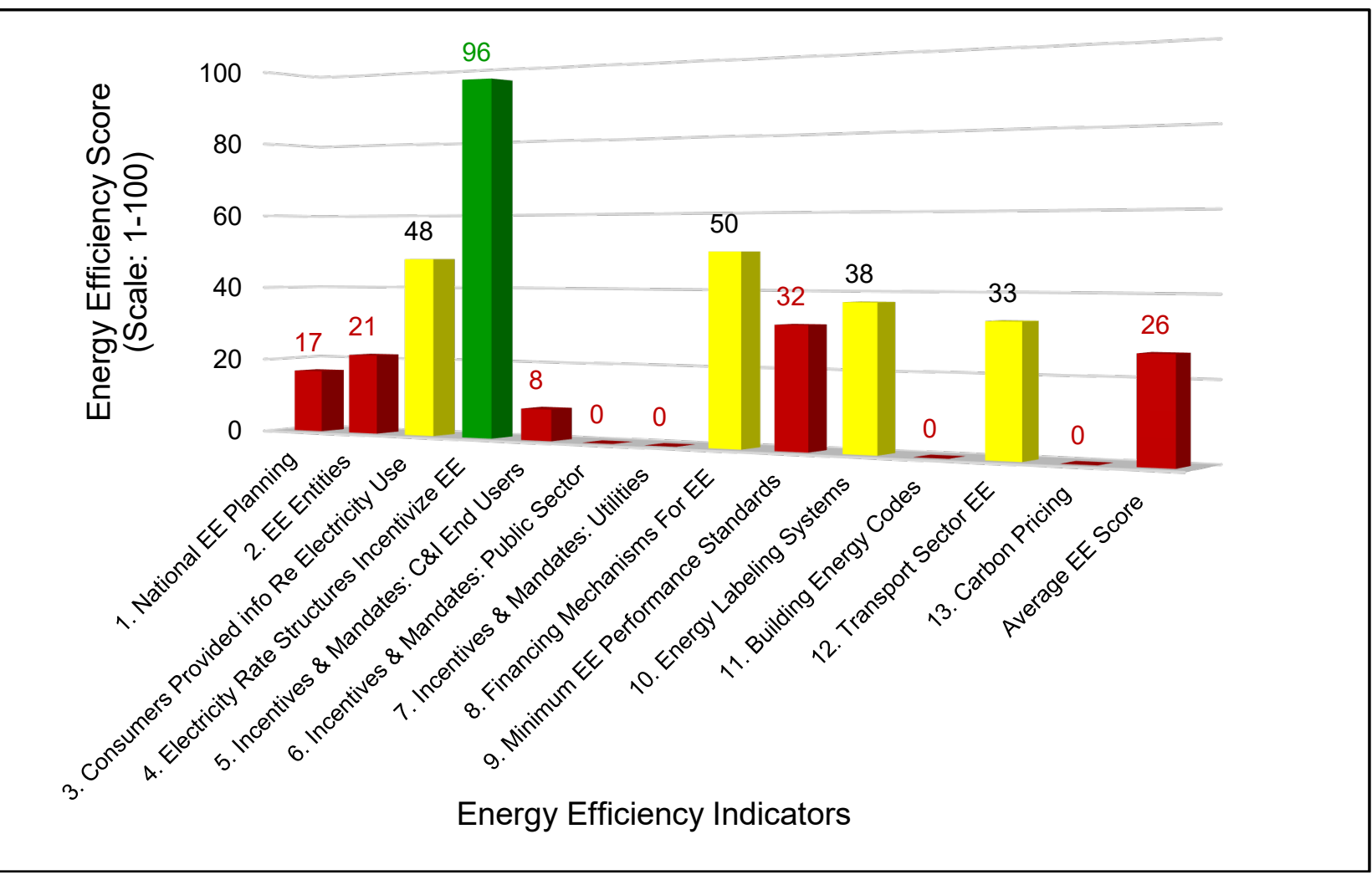

Figure 4. Dominican Republic 2017 World Bank RISE scores

Source: RISE 2017

\begin{abstract}
iii More details can be found on the World Bank's RISE web portal, https://rise.esmap.org/country/dominicanrepublic. Subsequent to this RISE scoring's publication, the Dominican government announced on December 11, 2018 that they have developed a draft NDC Plan of Action (POA) in the context of the COP24 conference. This POA articulates a roadmap towards achieving a much more climate-friendly energy profile. Thus, once this plan is finalized, and then these RISE scores are revisited, the Dominican Republic's numbers should grow. Nonetheless, these baseline measurements indicate significant room for continued improvement.

iv "Entities" refers to government and institutional compliance organizations in answer to three questions: (1) "Are there governmental and/or independent bodies that carry out formulation and implementation of EE strategy, policy and regulation for each of the roles listed below?"; (2) "Are energy efficiency programs developed based on market analyses with plans open to public consultation and periodic evaluation?"; and (3) "Are there professional certification/accreditation programs mandated for any of the following energy efficiency activities?" (RISE 2017b).
\end{abstract}


In fact, the only indicator scored, which ranks high enough to be considered a strong incentive towards energy efficiency, was the Dominican Republic's high electricity prices.

Through research and engagement with a broad spectrum of market stakeholders over recent years, NREL has identified additional challenges to C\&I energy efficiency investments in the Dominican Republic. These obstacles include: (1) a deficiency of project developers' working capital; (2) a lack of capacity to accurately value and assess the risks of energy efficiency projects; (3) recent structural challenges in the energy sector; (4) high interest rates; (5) banks' lack of technology knowledge and skepticism of long loan terms; and (6) and an overall difficult investment environment. Despite the high cost of electricity to Dominican consumers, these factors still have helped hinder the development of new energy efficiency upgrade projects.

\subsection{Government's Growing Energy Policy Attention}

The Dominican Republic's RISE scores point to a significant opportunity for the country to broaden and deepen its energy efficiency enabling environment. Multiple government offices have taken these issues seriously for a while. Moreover, the government has demonstrated, through its growing portfolio of efficiency-focused initiatives, that it recognizes the value of energy efficiency savings, and the importance of such policies to develop the market sector.

\subsubsection{La Comisión Nacional de la Energía's Energy Audits and Labelling}

The Dominican government established the Comisión Nacional de la Energía (CNE) following passage of 2001 electricity reform legislation. Among CNE's other roles, it serves as an equivalent to the US government's Federal Energy Management Program, seeking ways for government agencies to save energy. CNE eventually began conducting energy audits across the government. Through these audits, harnessing new energy monitoring software, from August 2013 to April 2014, CNE reduced its own energy consumption by 20\% (Konold, Lucky, et al. 2015). And in August 2015, CNE executed an energy audit of the public Colegio Dominicano de Ingenieros, Arquitectos y Agrimensores (CODIA). They "determined that there is a general potential for saving electrical energy of 26\%" (CNE 2015).

Today there is a simple, clear website through which any government agency can submit an online application for CNE to conduct an energy audit of their facilities (CNE 2020b); however, it is not clear how well resourced this program is. As the 2015 CODIA audit is the most recent one listed on CNE's web page, it is possible CNE has not had funds for many more audits in recent years. Moreover, it is unclear how much follow-through (essential for an audit to have any impact) CNE's client agencies have executed. As Worldwide Institute research in 2015 found, "Historically, energy efficiency audits in the Dominican Republic have relied on individuals to track and report data, but programs were quickly forgotten and there was no follow through from 'the top down'” (Konold, Lucky, et al. 2015).

CNE has explored policies promoting energy efficiency across the rest of Dominican society as well. Over five years ago, CNE determined that a national energy efficiency labelling program "could result in annual savings of approximately $350 \mathrm{MWh}$ of electricity and 222,000 tons of CO2 emissions" (Konold, Lucky, et al. 2015). Since then, four energy efficiency labeling programs have been adopted by the Instituto Dominicano para la Calidad: (1) NORDOM 644-self-ballasted compact fluorescent lamps; (2) NORDOM 655--energy efficient lighting for lamps; (3) NORDOM 780--Refrigerators and Freezers; and (4) NORDOM 834--air conditioning 
(Nunez 2018). Although the quantifiable impact of these labeling systems is still unclear, the government currently appears to be discussing developing energy efficiency labeling programs for even more types of equipment across a broad segment of industries and appliance sectors.

\subsubsection{Plan de Acción de la NDC de República Dominicana}

In 2015 the Dominican Republic published its intended $\mathrm{NDCs}^{\mathrm{v}}$ with a conditional emissions reduction target of 25\% off base-year emissions, by 2030 (INDC-DR 2015). Moreover, on December 11, 2018, in the context of the COP24 conference in Katowice, Poland, the Dominican government released an official NDC Plan of Action (POA) articulating its "priorities for the 2019-2021 period regarding legislation, finance and budgeting, monitoring and evaluation, and capacity building to strengthen climate action" (Mead 2019). One such priority is: "Incentives to increase energy efficiency and participation of non-conventional renewable energies"vi (Mead 2019). In support of this and other priorities, the POA is designed to:

"provide for planning, coordination, mobilization of resources and transparency in NDC implementation to advance realization of the Dominican Republic's development and climate objectives. It will be reviewed annually to ensure priorities are updated and included in the country's development plans." (Mead 2019)

Therefore, recent efforts indicate the Dominican government seeks to accelerate the deployment of energy efficiency and small scale renewables as two means of achieving both its climate and development goals, including broadening accessibility to clean energy cost saving measures, thereby encouraging economic growth. The government has also demonstrated other commitments to energy efficiency, including passing a July 2013 law (Law 100-13) that resulted in the formation of the Ministry of Energy and Mines (MEM) along with the formation of the Vice Ministry of Governmental Energy Savings. This new agency's intent is:

"To propose and administer energy savings and efficiency policies, and to formulate and implement the necessary regulations, technologies, programs, plans, and projects that permit increases in energy savings and higher levels of efficiency and energy sustainability in the Public Sector, as well as residential, manufacturing, transportation and services sectors, promoting a culture of responsible, rational, and efficient use of energy." (MEM 2020)

In 2018, the Dominican government also indicated it would take a number of actions to increase energy efficiency nationwide:

- Prohibiting the import of all fluorescent lights and mandating the country's transition exclusively to light emitting diode (LED) lighting (Renewable Energy Caribbean 2018).

\footnotetext{
${ }^{v}$ According to the United Nations Framework Convention on Climate Change, the plans by which countries announce their intention to reduce climate change-inducing greenhouse gas emissions known as NDCs, "are at the heart of the Paris Agreement and the achievement of these long-term goals. NDCs embody efforts by each country to reduce national emissions and adapt to the impacts of climate change" https:/unfccc.int/process-andmeetings/the-paris-agreement/the-paris-agreement/nationally-determined-contributions-ndcs.

vi In Dominican official policy the phrase "non-conventional renewable energies" refers to "hydroelectric, wind, solar, biomass and marine and other sources of renewable energy" (CNE 2004).
} 
- Implementing measures to enable more efficient electricity system operations and maintenance by distribution utilities, supported through a $\$ 400$ million Inter-American Development Bank (IDB) loan (IADB 2018b).

- Announcing their draft NDC POA on December 11, 2018, subsequent to publication of the RISE scores, including its roadmap toward achieving a much more climate-friendly energy profile. Thus, once the POA is finalized, the Dominican Republic's new RISE scores should grow the next time they are revisited. Nonetheless, the baseline RISE measurements currently indicate significant room for continued gains.

Many such initiatives have not yet been fully implemented-for example, the fluorescents ban/LED mandate. This policy, along with other potentially impactful energy efficiency measures, has been included in a series of legislative proposals whose development has been initiated by the MEM multiple years in a row. However, none of these policy proposals - despite their potential impacts - have been completed and passed into law by the Dominican Congress.

Additionally, the Dominican government's December 2018 draft NDC POA is comprehensive, detailed, and establishes ambitious goals; however, the POA was never finalized and adopted as official government policy. This is because, as of July 2020, MEM was in the process of revising the underlying NDCs. Thus, publication of the POA is now scheduled for the "first semester of 2021" (CNCCMDL 2020).

Nonetheless, the MEM has publicly set individual goals with potential significant impact. The MEM has pledged the country to reduce energy consumption by $13.2 \%$ by 2030 off a 2013 baseline (MEM 2019). This equates to annual savings of 3,279 GWh (Caraballo 2019). "If we achieve a savings of $10 \%$ in consumption," said outgoing MEM Minister Antonio Isla Conde, "we would be talking about an economic equivalent to the production of a 250-megawatt power plant" (Caraballo 2019).

There is also an opportunity for new momentum toward these goals with the July 2020 election of a new President, Luis Abinader, and his appointment of nuclear engineer Antonio Almonte Reynoso to lead MEM. President Abinader campaigned on a commitment to create 600,000 new jobs in four years. One of the stated pillars of this economic policy was a major electricity sector reformation, including "Expand[ing] the use of renewable energy to reduce the carbon footprint" (Guzmán Then 2019). And while he has not promoted energy efficiency itself, one month before his election, Abinader said, "We must guarantee the availability of energy, and try to increase the development of renewable energy every day, because sustainability and efficiency are decisive to achieving the productive and competitive potential of an economy" (N Digital 2020a).

And Almonte, while campaigning in June 2020 on Abinader's behalf, also without explicitly mentioning energy efficiency, expressed support for "sustainable practices":

"Luis Abinader ['s government] will be the government of clean and sustainable practices, we will incorporate in all productive sectors public policies and programs that facilitate access to clean non-polluting energies, this will make our national productive sector more profitable, generating benefits for all." (N Digital 2020b) 
Thus, there are some indications that the new administration, inaugurated in August 2020, may be proactive on addressing these issues.

\subsection{Potential Regional Collaborative Efforts}

Beyond the Dominican Republic, there are multiple regional energy efficiency efforts pointing to opportunities for increased energy savings among Caribbean islands in general. This is because most face similar challenges of reliance on expensive, imported fossil fuels. Even initiatives in which the Dominican Republic is not exclusively, or even directly, involved could positively impact its energy efficiency market. A robust regional energy efficiency ecosystem will likely catalyze opportunity aggregation across multiple small islands. Such ecosystem growth could also attract or develop regional energy service companies (ESCOs) who can operate in multiple countries and specialize in small island/Caribbean markets. Some such regional efforts include:

- The Caribbean Community's Energy Efficiency Strategy (Williams-Raynor 2016)

- Caribbean Centre for Renewable Energy and Energy Efficiency (CCREEE 2020)

- IDB and Caribbean Development Bank's Sustainable Energy Facility for the Eastern Caribbean (IADB 2018b; CDB 2020).

The Dominican Republic's current heavy dependence on imported fossil fuels for electricity generation reverberates through the economy. In 2014, burning imported petroleum generated $52 \%$ of Dominican electricity (Gielen et al. 2016). Because of this, the IMF estimated that a 2014 drop in oil prices, and a consequent decrease in the Dominican oil trade deficit, would precipitate an increase in net GDP growth of nearly 2\% (McIntyre, El-Ashram et al. 2016). Such dependence on oil imports for growth is inseparable from both economic volatility and declines; energy efficiency can provide a buffer from these destabilizing fluctuations. 


\section{Business-Level Market Assessment and Case Studies}

The potential value of energy efficiency is not only defined in abstract, economy-wide statistics. Smart, targeted energy efficiency investments by individual businesses across the Dominican Republic can save major proportions of their operating budgets every year.

Data from the World Bank and elsewhere indicates businesses across the Dominican Republic could harvest extraordinary benefits from energy efficiency upgrades. As Figure 5 shows, in 2016, more Dominican companies cited electricity as the second "biggest obstacle to their business," trailing only corruption (The World Bank 2016a). ${ }^{\text {vii }}$ Among all small businesses (5-19 employees) nationally, and among all businesses outside Santo Domingo, Santiago, Puerto Plata, and Espaillat, electricity was the most commonly identified top challenge, even more than corruption (The World Bank 2016a).

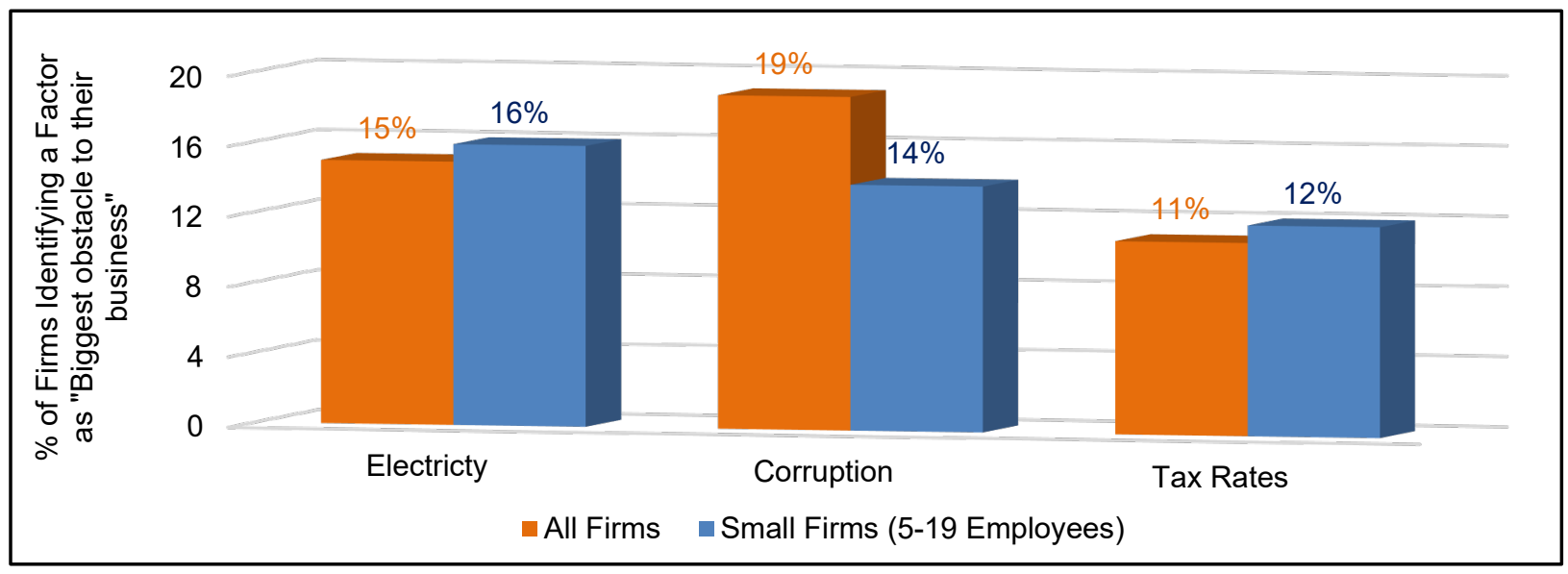

Figure 5. Top three Dominican Republic business environment constraints

Source: The World Bank 2016a

Additionally, as Figure 6 shows, even many of those businesses for whom electricity is not the top obstacle still consider it challenge. Over $37 \%$ of Dominican companies surveyed considered electricity to be a "major constraint," or more (The World Bank 2016a). viii

It is unclear the degree to which such firms considered electricity a constraint due to its price, the reliability of delivery, or a combination of both. Clearly outages are massive problem though. In this 2016 World Bank survey, 54.1\% of all Dominican businesses reported experiencing electrical outages. On average, these outages occurred 7.4 times every month. Across Latin

\footnotetext{
vii The survey asked "By looking at the list of elements of the business environment please tell me which one, if any, currently represents the biggest obstacle faced by this establishment," and "electricity" was listed as one of 15 options (The World Bank 2016b).

viii The survey asked, "Using the response options on the card; To what degree is Electricity a constraint to the current operations of this establishment?" Five answer choices were offered: (1) No constraint; (2) Minor constraint; (3) Moderate constraint; (4) Major constraint; and (5) Very Severe constraint (The World Bank 2016b).
} 
America and the Caribbean, only businesses in Guyana reported more outages on average, at 8.5 per month. And, in fact, this was nearly double that of the closest Caribbean state of St. Kitts and Nevis at 4.2 outages per month (The World Bank 2016a).

Dominican companies reported outages typically lasting four hours, the longest average duration in the Caribbean. This was such a problem that these firms speculated that they lost about 3.1\% of their total annual prospective sales revenue due to such outages (The World Bank 2016a).

These reported electricity challenges explain why nearly half (48.7\%) of all these firms owned or shared a fossil fuel back-up generator to compensate in some way. And surveyed Dominican companies who used a generator on average drew nearly $25 \%$ of all their electricity from their generator systems (The World Bank 2016a; McIntyre, El-Ashram, et al. 2016). Such generators typically use diesel or fuel oil and are much less cost-efficient per kWh than grid electricity. Thus, energy efficiency investments by firms that rely on generators could see a return on investment in an even more accelerated timeline than is the standard in the Dominican Republic.

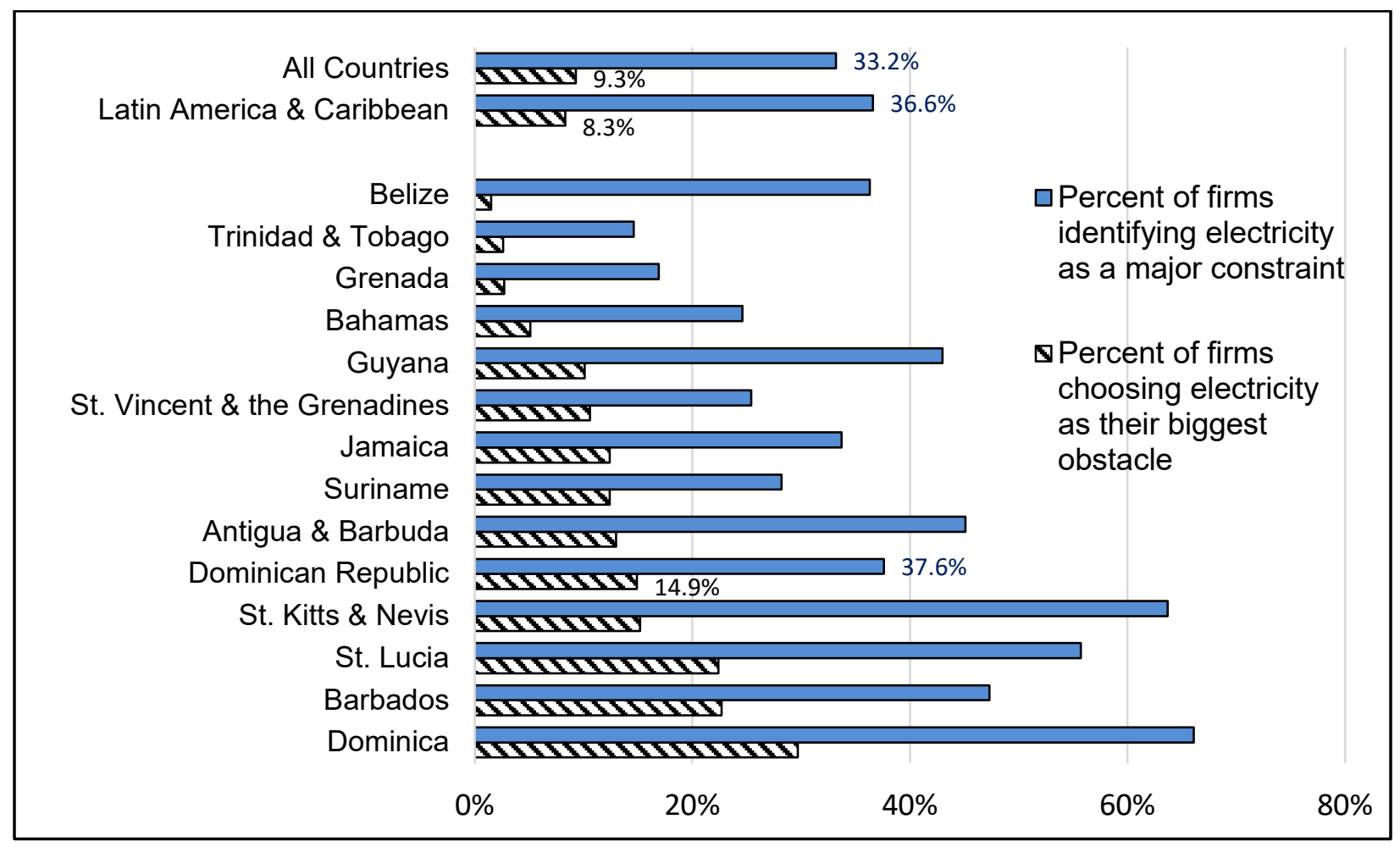

Figure 6. Electricity as a major constraint to firms

Source: The World Bank 2016a

When reviewing all these factors, the Dominican Republic appears ripe for the development of a robust energy efficiency sector. If a collection of quality - ideally local-ESCOs were to be providing such services, they could likely save their customers significant amounts of money, improve grid stability and reliability, and save the Dominican government millions of dollars every year in subsidy costs, while simultaneously reaping millions of dollars in revenue.

These numbers are not simply abstract, high-level theoretical assessments either. In particular, four subsectors used more energy (68.9\%) in 2018 than all other C\&I consumers combined. So 
focused efficiency efforts in the Cement and Ceramics (32.4\%), Sugar (16.0\%), Non-Sugar Food $(11.1 \%)$ and Hotels $(9.3 \%)$ industries, could make significant impacts in helping individual businesses lower energy consumption nationally (CNE 2020a). Case studies, such as the two below, have demonstrated specific methods by which businesses can save major portions of their annual operating budgets by investing in energy efficiency.

\subsection{Caribbean Hotel Sector Study}

The Caribbean Hotel Energy Efficiency and Renewable Energy Programme (CHENACT) was designed to benefit members of the Caribbean Tourism and Hotel Association by informing them of opportunities to improve competitiveness through investments in energy efficiency and distributed generation. The donor-funded program consisted of 144 energy audits and 30 walkthroughs, as well as policy support to the government of Barbados, Jamaica, and Bahamas (CHENACT 2012a; CHENACT 2012b).

The CHENACT study did not focus exclusively on the Dominican Republic, but it is still relevant, as the Dominican Republic "is home to more than a quarter of the Caribbean's hotel rooms and has the most hotels and the largest average hotel size in the region" (Konold, Lucky et al. 2015). Moreover, as seen in Figure 7, electricity accounts for over 65\% of Dominican hotels' energy consumption (Konold, Lucky et al. 2015). Many of the study's lessons may inform market opportunities for small- (20 to 40 room) and medium- (up to 300 rooms) sized hotels as it identified multiple energy saving measures with paybacks under five years, including improvements in lighting, appliances, HVAC, and behavioral and energy management practices.

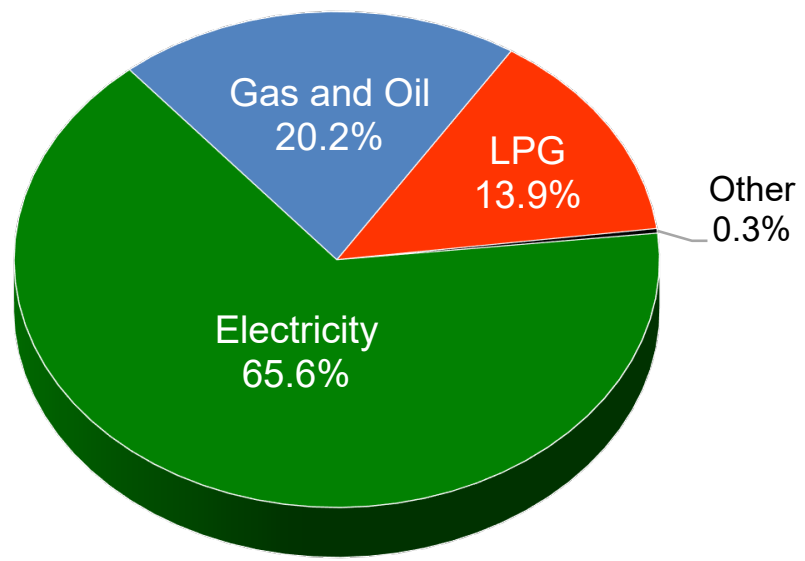

Figure 7. Energy consumption in Dominican hotels by fuel source

Source: Konold, Lucky et al. 2015

Such improvements not only pay rapid investment returns, they represent a critical scale of savings to individual small- and medium-sized hotels. ${ }^{\text {ix }}$ Electricity at times constitutes as much as $40 \%$ of all their expenditures, not just in energy (equal to about $0.2 \%$ of the entire Dominican

\footnotetext{
${ }^{\text {ix }}$ Up to 300 rooms in size.
} 
GDP) (Konold, Lucky et al. 2015). Thus, wise energy efficiency investment could save hotel owners over 13\% off their total costs (Konold, Lucky et al. 2015).

\subsection{Energy Conservation in the Caribbean}

Although this study evaluated energy efficiency opportunities in 2007, many of its lessons remain relevant in 2020. The research examined the range of energy costs across the Caribbean and estimated potential energy savings for individual energy efficiency technologies (as summarized in Table 1). The study's author also investigated the energy efficiency market sizes in the region and provided recommendations to regional entrepreneurs (Escalante 2007).

Table 1. Energy efficiency technologies that may be cost-effective in the Caribbean

Source: Escalante 2007

\begin{tabular}{|c|c|c|}
\hline $\begin{array}{l}\text { Type of Energy } \\
\text { Efficiency } \\
\text { Solution }\end{array}$ & Examples & Sample Benefits \\
\hline $\begin{array}{l}\text { Low-Cost } \\
\text { Solutions }\end{array}$ & $\begin{array}{l}\text { - Compact fluorescent lightbulbs }(C F L s)^{x} \\
\text { - Electronic timers } \\
\text { - Occupancy sensors } \\
\text { - CFL retrofits } \\
\text { - Efficient motors } \\
\text { - Refrigerant retrofits. }\end{array}$ & $\begin{array}{l}\text { CFL vs. Incandescent Bulbs: } \\
\text { - CFLs use } 70 \% \text { less energy } \\
\text { CFLs last } 8,000-10,000 \text { (versus } \\
1,000-2,000 \text { ) hours } \\
\text { Refrigerant retrofit costs } \$ 100 / \text { ton, } \\
\text { but saves } \$ 150 / \text { ton annually }\end{array}$ \\
\hline $\begin{array}{l}\text { Engineering } \\
\text { Services }\end{array}$ & $\begin{array}{l}\text { - Energy audits by certified engineer firms } \\
\text { - Designing Corporate Utility Management } \\
\text { Programs } \\
\text { - Energy efficient designs for new building } \\
\text { construction. }\end{array}$ & $\begin{array}{l}\text { Optimally designing facilities and } \\
\text { informing management practices } \\
\text { to maximize energy savings }\end{array}$ \\
\hline $\begin{array}{l}\text { Engineered } \\
\text { Solutions }\end{array}$ & $\begin{array}{l}\text { - Combined Cooling Heating and Power (CCHP) } \\
\text { - Solar hot water systems } \\
\text { - Chilled beams } \\
\text { - High efficiency AC } \\
\text { - Building envelope } \\
\text { - Desiccant heat recovery systems. }\end{array}$ & $\begin{array}{l}\text { CCHP is perfect for locations with } \\
\text { large demands for electricity, AC, } \\
\text { and hot water: } \\
\text { - hotels, offices, and hospitals } \\
\text { CCHP in Caribbean has potential } \\
\text { payback under two years }\end{array}$ \\
\hline
\end{tabular}

The author assessed several types of energy efficiency investments available to customers, including: (1) low-cost/no-cost solutions; (2) engineering services; (3) engineered solutions; (4) design/product development services; and (5) financial services. Table 1 is a summary of some of the key takeaways from the author's analysis. The table presents the first three types of

\footnotetext{
${ }^{x}$ In 2007, CFLs were an economical choice in the Caribbean; however, CFLs likely would not be the optimal choice for most uses in 2020. LEDs in 2020 tend to provide a significantly greater return on the investment than CFLs as LEDs are much more energy efficient, last much longer, and are even nontoxic. To replace a 100-W incandescent bulb, which produces about 1,600 lumens, would require a 23-W CFL, but only a 15-W LED bulb. Additionally, the CFL bulb only will last 10,000 hours on average, compared to an LED's average lifespan of 25,000 hours.
} 
investments listed above, specific examples from each category, as well as some tangible benefits derivable from such investments.

\section{ESCOs, Project Finance, and Performance Contracting}

As discussed above, multiple dynamics have impeded expansion of energy efficiency markets in the Dominican Republic, which could be addressed by efforts such as utility demand-side management, and incentive programs. However, there is a lack of "awareness on the part of businessmen of the [few] incentives and government measures" that already do exist (IADB 2020). Moreover, one of the most significant such impediments is the basic lack of understanding of such investments' economic value among both potential C\&I customers, as well as among the banks and other institutions that would finance such projects. "There is a lack of detailed knowledge about all the positive impacts that [energy efficiency] measures have on companies, financial savings, periods of return on investments, competitiveness, among others" (IADB 2020). Consequently, there are very few companies explicitly dedicated to the provision of comprehensive energy efficiency audit and upgrade services.

\subsection{ESCOs}

In the Dominican Republic, and in the Caribbean more broadly, there appear to be very few active, full-service ESCOs that implement energy efficiency upgrades. Thus, there are few companies advertising such services and providing essential market education. The absence of explicitly dedicated companies, with requisite expertise, constrains the potential growth of the energy efficiency upgrade sector; however, without the distinct demand necessary to support such firms, the sector remains mired in a chicken-or-egg loop.

One website indicates that there have been at least three major ESCOs active in the regionostensibly focused on Jamaica, Trinidad, Barbados, and the Dominican Republic since 2015 (Fortress Light 2017). Nonetheless, Dominican news reports indicate that the very first business ever founded in the Dominican Republic explicitly for executing full-service energy efficiency audits, upgrades, and other energy services, opened its doors in November 2017 (Nuñez 2017). Clearly the number of qualified ESCOs must grow rapidly if the energy efficiency market is going to scale any time soon.

\subsection{Project Financing Challenges and Low-Information Actors}

The Dominican Republic's largest ESCO (arguably the country's only national, full-service ESCO, which was mentioned in the 2017 news report) explained that most potential customers do not see how energy efficiency upgrades can be cost effective, so they do not seek out such services. And even if they do, the companies struggle to find financing for such investment. "It is not easy to access capital. The financial institutions do not understand that savings will pay for the project" (Oreanni Genao 2020).

Table 2, drawn from the 2012 CHENACT study, demonstrates the economic value of nine common ECMs. Every ECM, except PV, shows a payback period of two years or less. PV's payback period may be close to two years now, since solar installation prices have fallen over $25 \%$ and Dominican electricity prices have risen since 2012. It is slightly ironic then that 
Dominican banks seem to appreciate the return on investment for renewables, but not ECMs. Dominican banks offer financing for $80 \%-100 \%$ of the cost of an on-site PV system for creditworthy C\&I borrowers; however, their skepticism of the return on ECM investments means banks normally only lend up to $50 \%$ of the cost of such projects. This leaves ECM investments out of reach, or at least not cost-effective, for many businesses (Oreanni Genao 2020).

Table 2. Savings from Energy Efficiency Measures in Hotels in the Caribbean

\begin{tabular}{lllll}
\multicolumn{5}{c}{ Source: CHENACT 2012b } \\
\multicolumn{1}{c}{ Equipment } & $\begin{array}{l}\text { Electricity } \\
\text { Savings }\end{array}$ & $\begin{array}{l}\text { Cost Saved } \\
\text { Annually }\end{array}$ & $\begin{array}{l}\text { One Time } \\
\text { Investment }\end{array}$ & $\begin{array}{l}\text { Payback } \\
\text { Period }\end{array}$ \\
& $\mathbf{( G W H )}$ & $\begin{array}{l}\text { (Millions } \\
\text { USD\$) }\end{array}$ & $\begin{array}{l}\text { (Millions } \\
\text { USD\$) }\end{array}$ & (Years) \\
\hline Air conditioning & 340 & $\$ 105$ & $\$ 185$ & 1.8 \\
Lighting & 83 & $\$ 24$ & $\$ 18$ & 0.7 \\
Efficiency controls & 76 & $\$ 24$ & $\$ 41$ & 1.7 \\
Solar water heaters & 47 & $\$ 8$ & $\$ 9$ & 1.1 \\
Solar PV & 36 & $\$ 10$ & $\$ 39$ & 3.8 \\
Window film & 35 & $\$ 9$ & $\$ 19$ & 2.0 \\
Pool pump & 19 & $\$ 5$ & $\$ 3$ & 0.6 \\
Pump & 8 & $\$ 2$ & $\$ 1$ & 0.5 \\
Exhaust fan & 3 & $\$ 1$ & $\$ 1$ & 1.5 \\
\hline
\end{tabular}

Some efforts are being made to raise awareness among the financing sector of the value of energy efficiency investments. In late 2019, NREL joined with the IDB and a host of other Dominican and international organizations to launch a task force dedicated to promoting energy efficiency investment by the finance sector. The task force met in February 2020 and began focusing on a Green Bonds solution. The Green Bonds program was developed, but as yet not launched, by the Dominican government. The task force took on the mission of ensuring the program's success in scaling-up energy efficiency investment. It remains to be seen if this program achieves its promoters' aspirations.

\subsection{Performance Contracts}

One major business model that has helped catalyze the market in the United States for energy efficiency upgrades of existing facilities, and could generate significant benefits in the Dominican Republic, is the energy savings performance contract (ESPC). Under this model, the customer both pays zero money up front, and carries no loan on its official balance sheet; therefore, it involves very little risk to the customer. Instead, the ESCO itself finances the upgrades, either from its own assets, or more often by securing third-party financing. Then, the customer pays the ESCO a proportion of its monthly or annual savings. The presence and strength of ESCOs are a key indicator of the level of development of an energy efficiency market for the C\&I sectors. ESCOs provide a suite of services to their customers that offset the upfront cost and ensure that energy efficiency investments obtain the intended level of energy savings. 
As seen in Figure 8 (NREL 2015), the customer begins saving money immediately, and once the cost of the project is paid off, they begin realizing the full savings of their new-found energy efficiency. Often, the ESPC agreement specifies that if there is no energy savings, then the ESCO does not get paid at all. This of course incentivizes the ESCO to perform optimal work and ensure high energy savings and reduces risk to the customer.

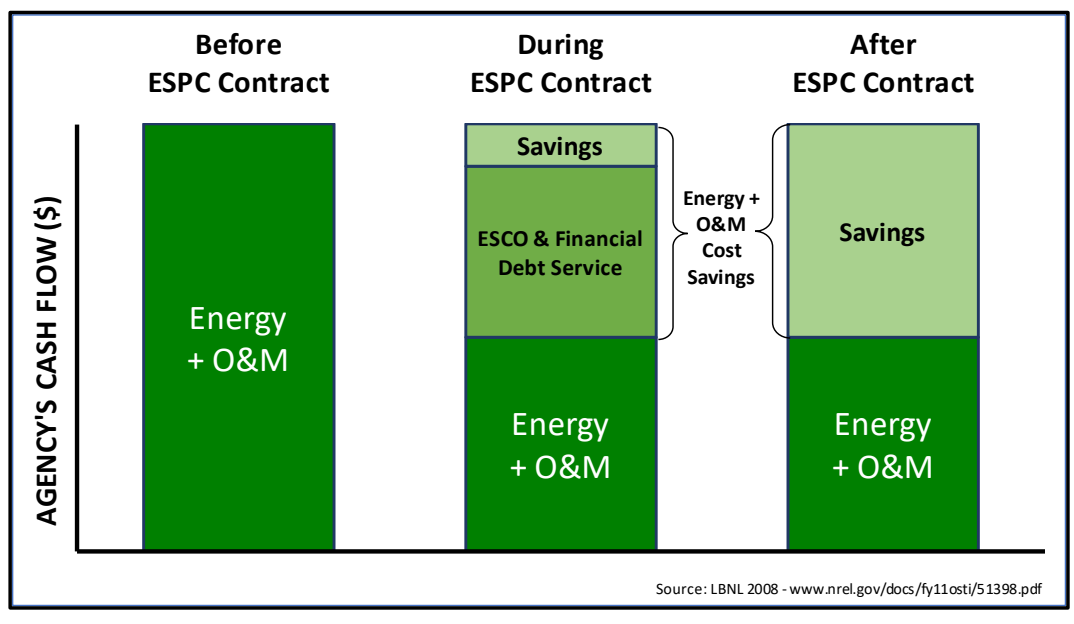

Figure 8. Cash flows under ESPC model

ESPCs, and the ESCOs that execute such projects, play crucial roles in a robust energy efficiency market, thus, cultivating a strong ESPC sector could potentially open significant revenue streams for both a quality ESCO and a savvy financing institution. Nonetheless, as previously noted, there are very few quality ESCOs in the Dominican Republic, and most financing institutions remain skeptical of the return on investment for ECMs. 


\section{Opportunity in Dominican Energy Efficiency}

Given the assessment in the previous pages regarding the Dominican energy efficiency market today, a private company may see conflicting signals as to whether energy efficiency upgrades can be an optimal short-term resource investment.

Therefore, in Table 3 a "Strengths - Weaknesses - Opportunities - Threats" (SWOT) analysis summarizes key lessons for such a prospective customer to consider. It presents both current strengths and weaknesses that could apply to the decision to move forward with energy efficiency upgrades. It also examines probable opportunities and "threats" their firms could face in the near to mid future implicit in efficiency investments.

Table 3. SWOT Analysis for Potential Dominican Republic C\&I Customers

\begin{tabular}{ll}
\hline STRENGTHS & WEAKNESSES \\
\hline - High energy prices help make the case for & - Nascent energy efficiency sector, including \\
energy efficiency investments & lack of locally-based, comprehensive ESCOs \\
- Strong solar resources plus generous & (especially that provide third-party financing for \\
renewable energy incentives can encourage & energy efficiency upgrades) \\
solar + energy efficiency investments & - Companies are not incentivized through public \\
- A wide variety of low upfront cost technologies & support mechanisms \\
are currently available & - Lack of affordable debt financing and loan \\
- Government's international commitments for & structures specific to energy efficiency \\
decarbonization drive interest in promoting & - Lack of local qualified energy auditors \\
energy efficiency and renewable energy & - Limited capacity among regional energy \\
technologies. & efficiency professionals to assess more \\
& complex investment opportunities. \\
\hline OPPORTUNITIES & THREATS \\
\hline - National and local governments may require & - Dominican energy efficiency technology \\
government contracts only from companies & providers are inexperienced and may install \\
investing in energy efficiency & equipment that does not provide savings as \\
- Government may launch incentive program & promised \\
subsidizing investment costs directly, or & - With rapid innovation in energy efficiency \\
through accelerated depreciation & technologies, a firm may install upgrades, and \\
- Government and international development & soon after a new, more efficient upgrade may \\
banks may be willing to back loans for energy & become available. \\
efficiency investments, lowering interest rates. & \\
- Banks may issue "green bonds," offering lower & \\
rates for energy efficiency financing & \\
- Programs to aggregate upgrades procurement & \\
can lower costs through economies of scale. & \\
- Programs to aggregate investment financing & \\
can help lower interest rates because of & \\
lender's risk diversification & \\
- Growing international market for "green" & \\
manufactured and food products. & \\
\hline
\end{tabular}


Despite the SWOT analysis listing multiple current weaknesses, the table also shows a significant set of opportunities. Moreover, many of those opportunities are efforts the government and private sector actors are aware of, have begun to act on, and are specifically designed to remedy key such weaknesses. Thus, multiple policies that the Dominican government has already identified for development and adoption-if effectively executedcould help remedy such market gaps and create significant opportunities for the rapid growth of the country's energy efficiency sector. Although it has not always done so, if the Dominican government is able to implement this host of contemplated energy efficiency programs, it could lead to millions of dollars in savings for both private companies and for the government itself. 


\section{Conclusion}

Energy efficiency investment has the potential to generate significant savings for the Dominican Republic's public and private sectors as well as could substantially reduce government expenditures on electricity subsidies. Expansion of the energy efficiency sector also could create greater opportunities for highly skilled, technical workers with high wages. Lastly, such investment could generate revenue for banks that finance the relatively low-risk, short-payback investments associated with energy efficiency. However, such a transformation of the energy efficiency sector will require the cooperation and buy-in from a divergent set of stakeholders from across the Dominican Republic. 


\section{References}

Banco Central (Banco Central de la República Dominicana). "Sector fiscal." Departamento de Programación Monetaria y Estudios Económicos, Balance del Sector Público No Financiero (Anual) (Base Devengada). Accessed July 15, 2020. https://www.bancentral.gov.do/a/d/4419.

BNEF (Bloomberg New Energy Finance). 2020a. "Country Profiles: Dominican Republic." Accessed July 15, 2020. https://www.bnef.com/core/country-profiles/DOM/commentary.

BNEF. 2020b. "Power Prices." Prices, Tariffs \& Auctions. Accessed July 15, 2020. https://www.bnef.com/core/data-hubs/5/29?tab=Power\%20prices.

BP. 2020. "Statistical Review of World Energy - all data, 1965-2020." BP Webpage. https://www.bp.com/en/global/corporate/energy-economics/statistical-review-of-worldenergy.html.

Caraballo, Joaquín. "República Dominicana tendría sustancial ahorro con plan de eficiencia energética." Diario Libre. March 5, 2019. https://www.diariolibre.com/economia/republica-dominicana-tendria-sustancial-ahorrocon-plan-de-eficiencia-energetica-HF12244300.

CCREEE (The Caribbean Centre for Renewable Energy and Energy Efficiency). "Home page." Accessed June 2020. https://ccreee.org/.

CDB (Caribbean Development Bank). "Sustainable Energy for the Eastern Caribbean." Caribbean Development Bank. Accessed June 2020. https://www.caribank.org/ourwork/programmes/sustainable-energy-eastern-caribbean.

CHENACT (Caribbean Hotel Energy Efficiency Action Programme). 2012a. Caribbean Hotel Energy Efficiency Action Programme (CHENACT) TC\#: ATN/OC-11465-RG: Energy Efficiency and Micro-Generation in Caribbean Hotels Consultancy: Final Report. http://www.caribbeanhotelandtourism.com/downloads/CHENACT-Final-Report.pdf.

CHENACT. 2012b. "Caribbean Hotel Energy Efficiency Action Program (CHENACT): Final Presentation." http://www.caribbeanhotelandtourism.com/downloads/CHENACTPresentation-Final.pdf.

CNCCMDL (Consejo Nacional para el Cambio Climático y el Mecanismo de Desarrollo Limpio). Email exchange with CNCCMDL's Planning and Development Division. July $17,2020$.

CNE (Comisión Nacional de Energía). "Plan Energético Nacional 2004-2015". July 2004. https://www.cne.gob.do/plan-energetico-nacional-pen

CNE. 2015. "CNE entrega auditoria energética al CODIA.” CNE Webpage. August 10, 2015. https://www.cne.gob.do/noticia/cne-entrega-auditoria-energetica-al-codia.

CNE. 2020a. "BNEN 1998 to 2018 - Updated May 13, 2019 (kTep)." El Sistema de Información Energética Nacional (SIEN), La Comisión Nacional de Energía (CNE) Webpage. Accessed July 10, 2020. https://www.cne.gob.do/estadisticas-energeticas/informacionestadisticas.

CNE. 2020b. "Auditorías Energéticas.” CNE Website. Accessed July 17, 2020. https://www.cne.gob.do/servicio/auditorias-energeticas.

El Día. "Gallup-Hoy: Delincuencia, desempleo y la inflación, principales problemas afectan a la mayoría." El Dia. May 8, 2019. https://eldia.com.do/gallup-hoy-delincuencia-desempleoy-la-inflacion-principales-problemas-afectan-a-la-mayoria.

Dirección de Regulación. "Evolución del Fondo de Estabilización de la Tarifa (Decreto 30203)." Provided via email on June 29, 2020 by Senior Economist from Dominican 
Republic Ministry of Energy's Dirección de Regulación, Superintendencia de Electricidad.

Escalante M.Sc. C.E.M., Andre. 2007. "Energy Conservation in The Caribbean - A Profitable Industry for Regional and Foreign Entrepreneurs." http://energydynamicslac.com/site/repository/files/EnergyConservation10 12 07.pdf.

Fortress Light. 2017. "The ESCO Environment in the Caribbean." Fortress Light. October 27, 2017. https://fortresslight.com/2017/10/27/caribbean-esco/.

Gielen, Dolf; Saygin, Deger; Gáfaro, Francisco; Portugal, Isaac; Gutiérrez, Laura; and Jil, Tomás. 2016. "Renewable Energy Prospects: Dominican Republic". REmap 2030, A Renewable Energy Roadmap. International Renewable Energy Agency (IRENA). Abu Dhabi. https://www.irena.org//media/Files/IRENA/Agency/Publication/2016/IRENA REmap Dominican Republic re port 2016.pdf\#page=55.

Guzmán Then, Abel. "Luis Abinader promises to promote 600 thousand jobs in four years: Proposes low-cost energy to power the industry." Diario Libre. November 26, 2019. https://www.diariolibre.com/actualidad/politica/luis-abinader-promete-fomentar-600-milempleos-en-cuatro-anos-LC15535529.

IADB (InterAmerican Development Bank). 2018a. "Dominican Republic to boost energy efficiency with IDB loan.” November 1, 2018. https://www.iadb.org/en/news/dominicanrepublic-boost-energy-efficiency-idb-loan.

IADB. 2018b. "IDB and CDB to expand the Sustainable Energy Facility (SEF) for the Eastern Caribbean." December 17, 2018. https://www.iadb.org/en/news/idb-and-cdb-expandsustainable-energy-facility-sef-eastern-caribbean.

IADB. 2020. Email exchange with IADB. September 3, 2020.

INDC-DR (Intended Nationally Determined Contributions - Dominican Republic). 2015. (Unofficial Translation) August 2015. https://www4.unfccc.int/sites/ndcstaging/PublishedDocuments/Dominican\%20Republic \%20First/INDC-DR\%20August\%202015\%20(unofficial\%20translation).pdf.

Konold, Mark; Lucky, Matthew; et al. 2015. Roadmap to a Sustainable Energy System: Harnessing the Dominican Republic's Sustainable Energy Resources. Worldwatch Institute. http://www.worldwatch.org/system/files/DR_report_English_hi-res.pdf.

Kost, C.; Mayer, J.; Thomsen, J.; Hartmann, N.; Senkpiel, C.; Philipps, S.; et al. 2013. Levelized Cost of Electricity Renewable Energy Technologies. Fraunhofer Institut for Solar Energy Systems (ISE).

https://www.ise.fraunhofer.de/content/dam/ise/en/documents/publications/studies/Fraunh ofer-ISE LCOE Renewable Energy technologies.pdf

Lazard. 2018. "Lazard's Levelized Cost of Energy Analysis-Version 12.0." https://www.lazard.com/media/450784/lazards-levelized-cost-of-energy-version-120vfinal.pdf.

McIntyre, Arnold; El-Ashram, Ahmed; Ronci, Marcio; Reynaud, Julien; Che, Natasha, Wang, Ke; Acevedo, Sebastian; Lutz, Mark; Strodel, Francis; Osueke, Anayo; and Yun, Hanlei. Caribbean Energy: Macro-Related Challenges (WP/16/53). March 2016. https://www.imf.org/external/pubs/ft/wp/2016/wp1653.pdf.

Mead, Leila. 2019. "Dominican Republic Launches Climate Action Plan with NDC Partnership." International Institute for Sustainable Development (IISD). Sustainable Development 
Goals (SDG) Knowledge Hub. January 8, 2019. https://sdg.iisd.org/news/dominicanrepublic-launches-climate-action-plan-with-ndc-partnership.

MEM (Ministerio de Energía y Minas). "Isa Conde: Es hora de revertir esta cultura de derroche en el uso de energía." Press Release. Website of Ministerio de Energía y Minas. March 5, 2019. https://mem.gob.do/sala-informativa/noticias/es-hora-de-revertir-esta-cultura-dederroche-en-el-uso-de-energia.

MEM. 2020. "Viceministerio de Ahorro Energético Gubernamental." Accessed July 12, 2020. https://mem.gob.do/nosotros/viceministerios/viceministerio-de-ahorro-energeticogubernamental.

N Digital. 2020a. "Luis Abinader expresa reformas del PRM abarcarán política, economía y programas sociales." N Digital Mulimedia. June 10, 2020.

https://n.com.do/2020/06/10/luis-abinader-expresa-reformas-del-prm-abarcaran-lapolitica-economia-y-programas-sociales.

N Digital. 2020b. "Comando de campaña de Abinader inaugura estación de carga de vehículos eléctricos." N Digital Mulimedia. June 12, 2020. https://n.com.do/2020/06/12/comandode-campana-de-abinader-inaugura-estacion-de-carga-de-vehiculos-electricos.

NREL. 2015. "Energy Snapshot: Dominican Republic." Energy Transition Initiative: Islands. https://www.nrel.gov/docs/fy15osti/64125.pdf.

Nuñez, Ali. "Abren primera tienda de eficiencia energética en la República Dominicana." almomento.net. November 25, 2017. https://almomento.net/abren-primera-tienda-deeficiencia-energetica-en-la-republica-dominicana.

Nunez, Melvin. "Establecerán políticas públicas sobre eficiencia energética." Website of El Instituto Dominicano para la Calidad (INDOCAL). April 11, 2018. https://www.indocal.gob.do/2018/04.

OECD (Organisation for Economic Co-operation and Development), IADB. 2017. "Government at a Glance, Latin America and the Caribbean 2017'. Country Fact Sheet, Dominican Republic. https://www.oecd.org/gov/lac-dominican-republic.pdf.

Oreanni Genao, Joan. Phone conversation with Joan Oreanni Genao, CEM, REP. Energuia. July $14,2020$.

Renewable Energy Caribbean. "Dominican Republic to become the first all-LED island in the world.” Renewable Energy Caribbean. April 18, 2018. https://renewableenergycaribbean.com/2018/04/18/dominican-republic-to-become-thefirst-all-led-island-in-the-world.

RISE (Regulatory Indicators for Sustainable Energy). 2017a. “The World Bank.” Accessed January 15, 2020. http://rise.worldbank.org.

RISE. 2017b. The World Bank. RISE-Dominican Republic Web Page. Accessed June 23, 2020. http://rise.worldbank.org/country/dominican-republic.

Taibi, Emanuele; Journeay-Kaler, Peter; and Bassi, Andrea. "Renewable Energy Opportunities for Island Tourism". IRENA. 2014.

www.irena.org/DocumentDownloads/Publications/IRENA_RE_Island_Tourism_report 2014.pdf.

Tetreault, T., and Regenthal, S. 2011. ESPC Overview: Cash Flows, Scenarios, and Associated Diagrams for Energy Savings Performance Contracts. Golden, CO: NREL. NREL/TP7A30-51398. https://www.nrel.gov/docs/fy11osti/51398.pdf.

The World Bank Group. 2016a. "Enterprise Surveys: What Businesses Experience: Dominican Republic 2016, Country Profile." The World Bank Group. 
www.enterprisesurveys.org/ /media/GIAWB/EnterpriseSurveys/Documents/Profiles/Eng lish/dominican-republic-2016.pdf.

The World Bank Group. 2016b. "Enterprise Surveys: What Businesses Experience: Survey Methodology." The World Bank Group.

https://www.enterprisesurveys.org/en/methodology

Williams-Raynor, Petre. "Energy-efficiency strategy coming for the Caribbean." The Gleaner. June 23, 2016. http://jamaica-gleaner.com/article/news/20160623/energy-efficiencystrategy-coming-caribbean. 